Meta

Journal des traducteurs

Translators' Journal

\title{
"... and he flew out of the window on a wooden spoon"
}

\section{Gaby Thomson-Wohlgemuth}

Volume 52, numéro 2, juin 2007

URI : https://id.erudit.org/iderudit/016064ar

DOI : https://doi.org/10.7202/016064ar

Aller au sommaire du numéro

\section{Éditeur(s)}

Les Presses de l'Université de Montréal

ISSN

0026-0452 (imprimé)

1492-1421 (numérique)

Découvrir la revue

Citer cet article

Thomson-Wohlgemuth, G. (2007). “... and he flew out of the window on a wooden spoon”. Meta, 52(2), 173-193. https://doi.org/10.7202/016064ar

\section{Résumé de l'article}

La traduction peut être vue en partie comme un transfert d'éléments culturels d'un texte à l'autre et, dans certaines circonstances, cela peut se produire entre des textes rédigés dans la même langue. Il s'agit en effet de la situation à laquelle les chercheurs font face lorsqu'ils analysent des versions anciennes est-allemandes des contes des frères Grimm et lorsqu'ils les comparent avec leurs originaux (dans la même langue). L'Allemagne de l'Est avait comme mission de venir à bout de la pensée capitaliste et de créer une nouvelle sorte de société. Le pouvoir permettait la transmission de quelques textes à leur public. Les contes étaient un des genres débattus avec véhémence, et plus particulièrement les contes des frères Grimm, en raison de leur position élevée dans le Troisième Reich. Cet article explore les premières traductions des contes des frères Grimm en Allemagne de l'Est, en examinant des éléments qui étaient considérés comme importants d'un point de vue idéologique, soulignés dans les textes, et ceux qui étaient jugés nuisibles à une éducation socialiste et désormais modifiés.
Ce document est protégé par la loi sur le droit d'auteur. L’utilisation des services d’Érudit (y compris la reproduction) est assujettie à sa politique d'utilisation que vous pouvez consulter en ligne.

https://apropos.erudit.org/fr/usagers/politique-dutilisation/ 


\title{
"... and he flew out of the window on a wooden spoon"
}

\author{
GABY THOMSON-WOHLGEMUTH \\ University of Surrey, Surrey, United Kingdom \\ gaby@asgard1.freeserve.co.uk
}

\begin{abstract}
RÉSUMÉ
La traduction peut être vue en partie comme un transfert d'éléments culturels d'un texte à l'autre et, dans certaines circonstances, cela peut se produire entre des textes rédigés dans la même langue. II s'agit en effet de la situation à laquelle les chercheurs font face lorsqu'ils analysent des versions anciennes est-allemandes des contes des frères Grimm et lorsqu'ils les comparent avec leurs originaux (dans la même langue). L'Allemagne de l'Est avait comme mission de venir à bout de la pensée capitaliste et de créer une nouvelle sorte de société. Le pouvoir permettait la transmission de quelques textes à leur public. Les contes étaient un des genres débattus avec véhémence, et plus particulièrement les contes des frères Grimm, en raison de leur position élevée dans le Troisième Reich. Cet article explore les premières traductions des contes des frères Grimm en Allemagne de l'Est, en examinant des éléments qui étaient considérés comme importants d'un point de vue idéologique, soulignés dans les textes, et ceux qui étaient jugés nuisibles à une éducation socialiste et désormais modifiés.
\end{abstract}

\section{ABSTRACT}

Translation may be viewed in part as a transfer of cultural elements from one text to another and, under certain circumstances, this may occur between texts written in the same language. This is indeed the situation researchers find when analysing the early East German versions of the Brothers Grimm's fairy tales and comparing them with their (same language) originals. East Germany was a country with a mission to overcome capitalist thinking and to create a new kind of society. Motivated by this, the establishment permitted only certain kinds of texts to reach their audiences. One of the genres vehemently debated in the early days was fairy tales and particularly so the Grimms' tales due to their high standing in the Third Reich. This article explores the first 'translations' of the Grimms' fairy tales in East Germany, investigating elements that were regarded as ideologically valuable and hence emphasized in the texts and those that were deemed harmful to a socialist education and hence modified.

\section{MOTS-CLÉS/KEYWORDS}

Brothers Grimm, fairy tales, East Germany, socialist ideology

\section{Introduction}

Every society seeks to show its children the values and norms it holds in high regard, in the hope that the children, as the next generation, will internalize these values and grow up to become citizens conformant and well-suited to their environment. Socialist Germany was no exception to this rule. However, extra importance was placed on the socialization process of the next generation, as East Germany was striving for a new social set-up. After the horrors of the Second World War, it was felt the time had come to create a new society, one in which people could - and indeed would 
- live in peace and respect each other. Yet the East German vision of this new kind of society was not restricted to humanitarian, peace-loving personalities. There were high aims for its glorious future destiny. Based on the belief that capitalism had brought about fascism - just as it had created, as was contended, many other evils - a radical change in the ideological structure was envisaged and socialism was the route to take. It is for this reason that the new citizens not only had to display humanitarian features but also those characteristics typical of what were claimed to be 'socialist personalities.' And how better to undertake this than to address children in their formative years, who are still naive and impressionable, a notion which was clearly expressed by East German children's author Holtz-Baumert who stated that "ultimately, the success in the education of our children will decide the fate of our nation" (as quoted in [Wille 1951: 319], my translation here and throughout).

Literature was one tool employed to engender social change and, as a result, the written word was attributed fundamental powers to affect such change. "Every reading act teaches insights, knowledge and realizations; it awakens good and bad qualities, it promotes or hinders a certain development; thus, every book contributes to the formation of a worldview in the readers [...]; consequently, every literature has a political effect; in this, the immense importance of literature becomes apparent, in order to educate and influence our people" (Bähring 1962: 8). Without doubt, in an environment in which literature played such a key role in shaping a society, it had become crucial for this society to maintain a close watch over its entire literary output and to produce only the kind of literature that supported the new ideas. Progressive children's books were called for, which "would contribute to forming a socialist consciousness in the readers and to their education" (Streul 1988: 5). The Kinderbuchverlag, i.e., the state publishing house for publications addressed to children aged 2 to 14, argued that superficial books of low quality should be tolerated to an even lesser degree in children's than in adult literature because children would be harmed by them, being so much more susceptible and open to education and moulding (Der Kinderbuchverlag 1963: no page). Attention ought to be drawn to the fact that the term 'low quality' not only meant in artistic or stylistic terms, but also referred to the spirit of socialism and to the fact that books with a bourgeois slant were no longer sought after. Taking this into consideration, every production had to consider its usefulness for society, in order to further the socialist cause (Hager, as quoted in [Rumland 1993: 9]). Only what was deemed suitable for creating citizens loyal to the state and its ideology was welcome. In this light, Margot Honecker, longstanding Minister of Education, defined the following requirements as suitable and desirable in books for children in a socialist state; in her view (and also in that of), they were to elicit in their young readers characteristics, such as "extraordinary efforts, courage, willingness to make sacrifices, will-power and being firm-principled"; they would further endeavour to strengthen ethical standpoints and behaviour, teach partisanship for noble ideals like social fairness, freedom, humanity and hatred against exploitation, suppression, slavery, aggression and immorality of any kind (1971: 71,74). This list might be completed by "love for peace, international understanding, human dignity and societal progress" (Günther et al, as quoted in [Wiesner 1991: 17]). Not every novel, not every story, not even every genre satisfied such demands. Girls' books were not a suitable genre, it was maintained, as they created women who were weak, dependent and certainly not strong enough to represent the socialist cause and fight for it. 
Neither, however, were fairy tales. This article describes the climate during the early years of East Germany with respect to the genre of fairy tales and to the Grimms' tales, in particular. It analyses the first two editions (i.e., five books in total) of the Brothers Grimm's fairy tales, exploring the alterations made to the tales and providing an indication of the political and ideological background driving these decisions.

\section{East Germany and its attitude to fairy tales and to the tales of the Brothers Grimm}

Especially in the 1940s and early 1950s, vehement debates were raging about the value, or rather lack of value, in fairy tales. Notably in the 1940s, i.e., directly after World War II, sceptical voices pointed to a connection between the cruelties committed by National Socialism and those depicted in fairy tales. Equally, fairy tales were rejected because miracles and fantasy were in conflict with the dogma of Socialist Realism, i.e., the literary principle postulated by the Socialist Unity Party. Claiming that fantastic elements seemed incompatible with the education of a rational and realistic behaviour (Emmrich 1987: 64), it was feared that children's perceptions of realism would become distorted. Fairy tales showed children an unreal world, in which nature was full of magic creatures who were responsible for keeping the world turning, whereas the new, progressive education was aiming to teach a realistic picture of the environment to the children (Brandt 1951: 321). Another objection against fairy tales drew on the socialist arguments of the 1920s in which fairy tales were regarded as showing backwardness and the dependence of the lower classes caused by their servitude. Similarly, it was questioned "whether it was at all justifiable to tell fairy tales, in which kings, princes and princesses were the main actors, to our children in our times, particularly since children were educated at school about the true conditions of feudalism" (Wardetzky 1991: 8). A case in point is the pressure put on one of the children's book publishers in the 1940s who wished to bring out a folktale entitled 'Princess Frog,' a version of the Grimms' The Frog King. The East German authorities refused a print permit unless the story was renamed 'Miss Frog', thus stressing the progressive, anti-feudal attitude prevalent in society. Ironically, it was only through intervention by the Soviet Occupation Power that the story was eventually published, keeping the title originally suggested (Holland 2000: 80).

All these notions are indicative of a rather narrow-minded discourse on realism which did not allow for a more multi-facetted outlook on life. They reveal the overly dogmatic behaviour of the early years, helping to create uncertainty about the values of fairy tales for the new society of the future, which was in the process of emerging and developing. As a result, only particular tales which matched the socialist conception of the world were selected. Also in the 1950s, mainly adapted versions were published in which critical passages were left out or changed. So, for example, radio programmes of that time sought to equip fairy tales with a progressive touch, by, say, having the hero refuse the crown because he would much rather be a head forester than a king, or by making him use his newly attained power to introduce social reforms (Göritz 1986: 155,156). In addition, didactic commentaries were added to justify attitudes in the sense of a socialist ideal of mankind. One of these commentaries, for example, describes the tale 'Mother Holle' (Frau Holle) as being highly valuable because it awakens love for work [...]; in 'King Thrushbeard' (König Drosselbart) the 
moral is quite evident, as the arrogant and lazy princess has to be taught honest work by Thrushbeard, who had disguised himself as a beggar" (Wardetzky 1991: 8). Although these comments appear pedantic, they were nothing other than an attempt to legitimize fairy tales, in order to preserve them for children.

What follows is a closer analysis of the first publications of the Brothers Grimm's fairy tales acquired for the East German market and the restrictions under which this took place. On the whole, the introduction of Grimms' folktales entailed difficulties in view of their previous high standing in the Third Reich, because anything associated with National Socialist worldview was declared incompatible with the East German socialist belief system. German fascism had used these folktales as one of its main cultural assets, teaching children their past as rooted in the Nordic Germanic tradition and thus representing the very essence of 'Germandom' (Kamenetsky 1992: 242-247). As a result, in the aftermath of the Second World War, questions were raised about their value and whether they could be harmful to the children reading them or listening to them. So, for example, Arnold Zweig (1948: 59) maintained that 'The Jew in the Thornbush' (Der Jude im Dorn) created anti-Semitic attitudes which were seen as a danger after the experience of the War; equally, the tale 'Hansel and Gretel' (Hänsel und Gretel) was linked to Nazi incinerators because of the oven into which the witch is pushed in the tale. These reservations notwithstanding, the Brothers Grimm could not be ignored in East Germany as a contribution to the great German literary heritage; even more so as the tradition of the Grimms' fairy tales was deeprooted in households and people kept asking for the tales in the bookshops.

Therefore, despite many reservations, the decision was made to re-issue the fairy tales in a new edition, published by Kinderbuchverlag. The tales came out in two editions, approximately at the same time. The first edition consisted of three volumes, brought out in 1952, 1953 and 1955 respectively and the tales were selected and edited by Dr. Walther Pollatschek (henceforth P1952; P1953; P1955). The second edition comprised two volumes, published in 1955 and 1956 and its tales were selected and adapted by Dr. Anneliese Kocialek (henceforth K1955; K1956).

In total, 94 out of the 211 Grimms' tales were chosen to be included in Pollatschek's and Kocialek's collections. The three books of the first edition had 79 stories while the second edition had 68, which demonstrates a fairly equal spread in number considering that Pollatschek's edition consisted of three books and Kocialek's only two. Another fact worth mentioning is that Pollatschek's edition used every story only once, whereas Kocialek selected 11 stories to appear in both of her books (details of the stories in each book are provided in a table at the end of this article, including the titles of the selected fairy tales in English and German). Both editions appear to share the same selection criteria, which can be divided into four categories: stories with a non-magical narrative; stories with animals as protagonists; stories well-known and well-entrenched in the German tradition; and also stories which may be lesser known in the German culture but which display one or more attributes of a socialist personality, as it was understood at that time. Another noteworthy detail is the fact that volume P1955 included four tales, one of which (The Griffin) had been written in Alemannic by the Grimms and three in Low German (The Gnome; The Hare and the Hedgehog; The Fishermen and his Wife). In this volume, these four tales appear both in their original rendering but also in High German. When comparing both versions with the Grimms' original, one finds the versions in the old German languages 
untouched, whereas the modernised versions of the same stories were edited. This seems remarkable and would suggest the high respect which the East German editor held for the authority of the source text; another reason, however, might be that it was assumed that the child audience would not be sufficiently educated or patient to dig its way through the original verson. Kocialek's volume from the year 1956 similarly incorporates two tales in the original and High German version, one in Alemannic (The Peasant in Heaven) and one in Low German (The three little Birds). While The Peasant in Heaven has Grimms' version without any alteration, the close of The three little Birds had been modified in the Low and High German version; both have "Die falschen Schwestern wurden verbannt [banished]," while Grimms write in the original "verbrannt [burnt]." Kocialek's solution leads to the belief that, despite the fact that the originals appear to have been held in high esteem in the German Democratic Republic (GDR), concern for the readers' harm was predominant, even more so as it was only a single letter that had to be blotted out, a fact which might have made the decision easier as to whether or not the source should be altered.

From an ideological perspective, it is understandable that neither of the two editions has cared to include the two tales with a Jewish theme because of their negative portrayal of Jews (The good Bargain; The Jew in the Thornbush) or those tales with religious overtones, e.g., The three Languages or the ten Children's Legends. Another observation is that Hänsel und Gretel, one of the most popular fairy tales in the German tradition, entered the collection only in 1956, i.e., in the last of the five volumes, a fact that may be put down to the aforementioned antagonism to Hitler's regime with its gas chambers. Furthermore, while the Third Reich deemed "simpletons 'unworthy' of consideration within the new racial peasant policy that tried to project the image of racial strength and superiority" (Kamenetsky 1992: 244), this was not the case in the GDR. Five stories (The Queen Bee; The three Feathers; The golden Goose; The Story of the Youth who went forth to learn what Fear was; The Griffin) were included in these five volumes, portraying a Dummling (simpleton) as the hero, because it was not superiority that counted but personal courage, initiative, action, and motivation to change the status quo for a better life, for the utopia of communism. As long as everybody carried their share in this process, they were considered worthy by society, regardless of their intellectual capabilities.

On the basis of what has been said so far, it seems understandable, firstly, that only those of Grimm's tales were chosen that would cross well into socialism and aimed at depicting the right spirit; secondly, it appears reasonable to assume that modifications were made, if a tale did not entirely fit the requirements. After investigating the corpus of 94 tales from all five books, 52 are found to have had changes made to them in some form or another. What becomes evident is the fact that the earlier edition (i.e., Pollatschek's three books) had resorted to more text alterations (that is, more in terms of number and severity of the modifications) than Kocialek's and, on many occasions, the second edition (Kocialek's) restored the original writing by the Brothers Grimm, albeit never returning them fully to their original status. This seems remarkable, given that both editions were published by the same publisher and have overlapping publishing dates $(1952,1953,1955$ versus 1955, 1956). A reason for this may be that, even in such a short space of time, fairy tale discourse had progressed, that horizons had widened and that overall awareness of the German cultural heritage had risen. Also at the same time, discussions about the value of translation of foreign books had 
commenced nationwide and many voices argued for a more faithful handling of originals and for more respect and faithfulness to the author of a work.

What, then, did the two editors regard as inappropriate for children's eyes? What did the bureaucracy allow to pass as ideologically acceptable?

\section{Modifications independent of socialist ideals}

In a similar fashion to translation of children's texts into other languages, Grimms' tales were 'translated' into East German, resulting in several kinds of alterations. So, for example, a great number of expressions of a violent and erotic nature were eliminated in all the five volumes on their journey into the socialist German culture.

The following violent phrases, which find themselves, in general, frequently deleted in fairy tale translations, were also omitted in the five East German volumes. They are

1. the hare falling to the ground, blood streaming out of his mouth, after his race with the hedgehog (The Hare and the Hedgehog)

2. the wolf drowning miserably (The Wolf and the seven young Kids)

3. the hunter drawing off the wolf's skin (Little Red-Cap)

4. the marshal being torn apart by four oxen (The two Brothers)

5. Snow White's stepmother has to dance in red-hot iron shoes until she drops down dead (Snow White)

In the first three fairy tales, all references were deleted without any replacement. The fourth example shows modifications in that Pollatschek writes that the marshal is thrown into prison (P1953), whereas Kocialek speaks about a judgement that the marshal deserved his death (K1955). Snow White's new ending by Pollatschek and Kocialek read,

"There the shock turned her so ugly. So ugly no human being wanted to look at her, and she did not want to look into her mirror. She ran out into the big, wild forest and nobody has ever seen her again or knows what has become of her" (P1953)
"And for fear and shock she stood there and could not move. There her evil heart burst and she fell to the earth dead" (K1955)

Another 'tamed' ending is that of Rumpelstiltskin which, in the original has a fairly graphic description. Rumpelstiltskin in his anger plunges his right foot so deep into the earth that his whole leg goes in; and then in rage he pulls at his left leg so hard with both hands that he tears himself in two. Both, Pollatschek (P1953) and Kocialek (K1955) cut by making short work of the ending and declaring succinctly "and he flew out of the window on a wooden spoon."

Two witch episodes deserve mention. In the tale The two Brothers, the Brothers Grimm have the two brothers seize the witch, bind her, put her into a fire and burn her. Not so in East Germany. Pollatschek (P1953) writes, "The poison grew in her heart so much that she exploded," whilst Kocialek (K1955) writes, "then they [the two brothers] got hold of the witch and hit her with the magic wand on the back so that she turned into stone."

The witch in Hansel and Gretel (K1956), is not allowed any of the following thoughts from Grimms' original, 
"When a child fell into her power, she killed it, cooked and ate it, and that was a feast day with her. Witches have red eyes and cannot see far, but they have keen noses like beasts, and are aware when human beings come near. When Hansel and Gretel came into her neighbourhood, she laughed maliciously and said mockingly, „I have them, they shall not escape me again!"

Yet another child-devouring scene from The seven Ravens was thought unsuitable for the East German audience, which in the original tells the child readers, "She walked far until she came to the end of the world. There she came to the sun, but the sun was too hot and too terrible and devoured small children. Quickly she ran away to the moon, but the moon was too cold and also awful and malicious and when it noticed the child, it said 'I am smelling, smelling human flesh'”; Pollatschek (P1952) turns this into a succinct "... but the sun was too hot, quickly she ran away to the moon but the moon was too cold."

In a country, seeking to transform its populace, education in the spirit of humanity was seen as seriously endangered, should the young readers hear the following cruel deed (The white Snake) from an otherwise empathetic boy who helps all the suffering creatures he meets on his way (and who therefore constituted an ideal role model for East German readers). The boy comes across, amongst others, little ravens who had been thrown out of their nest by their parents and are dying of hunger. So the good boy dismounts and kills his horse with his sword and gives it to them for food. Pollatschek (P1953) replaced this by, "The good boy took from his saddlebag all his food rations, without even thinking about his own needs, and gives to the ravens what should have served to feed him." This definitely brought home to the children the ideal of unselfish thinking, even if this meant that one had to sacrifice one's own food for the benefit of the others.

Finally, medieval methods of torture and killing were clearly unacceptable. Every single mention of a gallows was removed (The blue Light; The Gnome; The four skilful Brothers; The Story of the Youth who went forth to learn what Fear was; as a matter of fact, in the later tale the whole episode had disappeared, in which Dummling takes the corpses from the gallows and tries to warm them at his fire). Similarly, barrels with nails on the inside, in which evil people were rolled to their death were unsuitable. In The Goose Girl and The three little Men in the Forest both, Pollatschek and Kocialek, were content with the solutions of either having villains stealing away secretly, overtly running away, or also being chased out of the country.

On the whole, the tales selected for the five GDR volumes contain hardly any reference to eroticism. Where, however, such occurrences exist, they appear to have posed a problem for the editors, which is the case with The two Brothers and All-kindsof-Fur. In The two Brothers, the twin brother comes to the royal court, in the search of his brother, and is mistaken for his brother, the husband of the queen. The Brothers Grimm continue, "in the evening, he was taken to the royal bed, but he put a doubleedged sword between the young queen and himself. She did not know what this should mean but she did not dare to ask"; it causes an argument between the two brothers later when the young king finds out that his brother has slept in the same bed as his wife and he chops his brother's head off, albeit regretting his deed soon afterwards and, with the touch of a root of life reviving him again; however, "in the evening when the young king went to bed, his wife said, 'why did you lay the two-sided sword in our bed in the last nights, I thought that you wanted to kill me,' there he 
realised how loyal his brother had been." Both East German versions (P1953, K1955) considered the mention of sharing the same bed, of the sword in the bed and, in the end, the recognition of the brother's faithfulness as too sensitive and removed both instances. However, while Pollatschek in 1953 also removed the entire scene in which one brother, out of jealousy, chops off his brother's head, Kocialek two years later decided to leave this scene in the story. It is a reasonable guess that this was done, because this scene does not include notably erotic allusions and can be read and understood in an innocent fashion and, unlike the other instance, might not have resulted in questions by the children as to the reason for the sword in the bed, hence embarrassing any parents or educators by putting them on the spot.

The second hint at an erotic instance, implying incest between father and daughter, is found in the following scene in All-kinds-of-Fur where Grimms' original (G) and the East German versions read:

"[The king had a daughter
who was as beautiful as her
late mother ...], he felt
burning love for her. He said
to his advisers, 'I want to
marry my daughter, because
she looks just like my late
wife and I cannot find a bride
who resembles her'. When the
advisers heard this, they were
shocked and said, 'God has
forbidden a father to marry
his daughter; nothing good
comes from sin, and ruin will
be brought to the kingdom.'
The daughter became even
more shocked..." (G)

"[The king had a daughter who was as beautiful as her late mother .... , he felt burning love for her. He said to his advisers, 'I want to daughter because she looks just like my late who resembles her'. When the advisers heard this, they were shocked and said, 'God has forbidden a father to marry his daughter; nothing good comes from sin, and ruin will The daughter became even

"[The king had a daughter
who was as beautiful as her
late mother ...], he said to his
advisers, 'I want to marry my
daughter, because she looks
just like my late wife and I
cannot find a bride who
resembles her. The daughter
became frightened..."
(P1953)

Both East German versions found it impossible to speak about the burning love of the king for his daughter and resorted to deletion. This example reveals another sensitive area which will be discussed in the following section and which, in the GDR, resulted in deletions on a regular basis, i.e., religion and any mention of God or religious practices.

\section{Modifications due to socialist ideology}

It becomes immediately discernible that one controversial area in the developing East German society dealt with issues around class and poverty versus wealth. This attitude is illustrated not only by instances of elimination of shorter and longer paragraphs, but also by insertions of instructive explanations, as will be elaborated below.

The moral of The Hare and the Hedgehog, whereby a man planning to get married should take a wife from his own class, clearly did not fit the new ideals and disappeared. Similarly, telling children that "nowadays it no longer happens that people can cry pearls instead of tears, otherwise the poor would soon become rich" (The Goose Girl at the Well), was regarded unsuitable for a society in which people were equals and being poor was nothing to be ashamed of. 
Another example is taken from Iron John, in which a prince hides the true nature of his birth and works as a gardener's boy, yet manages to save the kingdom through bravery and readiness for action. After the battle, the king says to him, "If you are capable of such deeds, then you cannot be a gardener's boy. Tell me who is your father?" "My father is a powerful king and I have gold more than enough and as much as I require." It appears that both editors (P1953, K1955) took this conversation as discriminatory against the working class and thus not necessary for the comprehension of the tale and removed it, together with the princess's answer "I have already seen by his golden hair that he is no gardener's boy."

The notion that a princess was no better than ordinary girls must have been on Pollatschek's mind, when he modified the following passage (The two Brothers),

\begin{abstract}
"Outside the town there is a high mountain on which there lives a dragon; every year, he must have a pure virgin, otherwise he will lay the whole land waste. Yet, all our virgins have been sacrificed and there is no longer any left but the king's daughter, yet there is no mercy for her, she must be brought to him, and this shall happen tomorrow." (G)
\end{abstract}

\begin{abstract}
"Outside the town there is a high mountain on which there lives a dragon; he has demanded the king's daughter be brought and fed to him, otherwise he will lay the whole land waste. Therefore, there is no mercy for her, she must be brought to him, and this shall happen tomorrow." (P1953)
\end{abstract}

Interestingly, Kocialek (K1955) brought back Grimms’ version in 1955, disregarding its non-socialist interpretation.

Several times, further explanations to the text were added, so as not to leave the young readers in any ambiguity. The majority of these again revolve around questions of class. It appears children were guided towards believing that wealthy people and people of a higher class tended to be evil. So, e.g., in The white Snake,

\footnotetext{
"The servant refused everything and only asked for a horse and travel money, because he was keen to see the world and to go about a little" (G)
}

"The servant refused everything offered to him and only asked for a horse and travel money, because he did not want to stay with a king who had committed such great injustice and had threatened to take his life" (P1953)

Equally, in the closing sequence of How six Men got on in the World, six men are being followed by the king's regiments to stop them carrying away the king's treasures. But instead of battling, the Blower blows a big blast of air towards the followers.

\footnotetext{
"There the regiments were driven away from each other, one here and one there. The sergeant asked for mercy, saying he had nine wounds and was a nice fellow who did not deserve ill-treatment. There the Blower stopped a little so that he could come down unharmed. Then he said to him, Go home and tell your king that he should send more horsemen, I would like to blow all of them high up into the air'. When the king heard this, he said, 'let them go, they have the best of it.' Then the six took home all their riches, shared them among each other and lived happily until their death" (G)
}

"There the regiments were driven away from each other, one here and one there. This is how people fare who defend an evil king. The six however went away and lived happily together. And what did the king do? This I don't know exactly. For sure, he has never again sent away a soldier with three pennies travelling monies if, at all, he has found any soldiers who would go to war for him" (P1952) 
This example also shows another fact, held in high regard by socialism; the six in the East German version do not take their riches with them, they prefer rather to be together and live happily in each other's community. This reflects the socialist virtue that money is not important but rather the 'collective' and mutual support.

Most certainly, the insertions and radical changes in the following example were motivated by a protective bias towards the working and farming classes and perhaps also by an attempt to teach children about the 'true nature' of the well-to-do. It is found in the closing section of The three Feathers, in which the three sons are asked to bring home the most beautiful woman, in order to inherit the kingdom; the simpleton brings home a beautiful, delicate maiden who was given to him by a toad, while his two brothers make another choice.

"His brothers came home and they had given themselves no trouble at all to seek beautiful girls, but had brought with them the first best peasant women they chanced to meet" $(\mathrm{G})$
"In the meanwhile his brothers had gone out, and one of them had taken the richest woman he could find, because he thought that there was nothing better than riches, and therefore she had to be the right one. But the other one had taken a duchess and he thought that she was the noblest in the land, and therefore she had to be the right one" (P1953)

When the king decides that the simpleton should receive the kingdom, the two brothers demand a further trial, insisting that only the son whose bride could leap through a ring should be the future king:

"They thought that the farmer's wives could do that easily, they are strong enough, but the delicate maiden will jump to her death [...]. There the two farmer's wives jumped, managed to jump through the ring but were so stout that they fell and broke their coarse arms and legs. Then the beautiful maiden jumped whom simpleton had brought, and she jumped so lightly like a deer...” (G)

\begin{abstract}
"But they thought that the bride of their youngest brother would not be able to do so because she was so fine and delicate. Then the rich woman and the duchess jumped but, because they had done nothing but eating, drinking and lazing around for all their life, they were not capable of jumping through the ring and broke their arms and legs. Then the beautiful maiden jumped who had been a little toad and who had learned to move and busy herself. She jumped so lightly like a deer..." (P1953)
\end{abstract}

The example below (Iron John) also makes use of additions and, no doubt, the insertion at the end was meant as altruistic instruction to demonstrate to the young readers the virtue of giving and to drive home to them the point that one will receive, if one gives.

\footnotetext{
"He went to the young man, embraced him and said, 'I am Iron John and was by enchantment a wild man, but you have set me free; all the treasures which I possess shall be your property." (G)
}

"He went to the young man, embraced him and said, 'I am Iron John and was by enchantment a wild man, but you have set me free and with me all people and animals who I had to rob and put under a spell, as long as I was under an enchantment. As I have helped you to your happiness, you have been given the power to help me to my happiness.' There celebrations began and whoever tells about them wishes they had been there" (P1953) 
As in a previous example above, this instance shows the low regard for possessions in a socialist society, as Pollatschek did not care to mention Iron John's treasures in his version; yet again it is interesting to see Kocialek re-install Grimms' original words two years later.

The significance of humanity for the GDR society manifests itself in the way in which concepts of serving, ruling, equality of men and women and parental love are expressed in texts for children, as is illustrated below.

\footnotetext{
"Your sisters shall serve with a charcoal burner until they have bettered themselves" (The Hut in the Forest)

"But I would like to have my servant run instead of me" (How six men got on in the world)

"... and both ruled over their kingdom happily and peacefully" (The Goose Girl)

"Hold your tongue, woman, this is my affair. Don't interfere in man's business (The Hare and the Hedgehog)
}

\begin{abstract}
"Your sisters shall stay with a charcoal burner until they have bettered themselves" (P1952)

"But I would like to have my companion run instead of me" (P19521)

“... and both lived in their kingdom happily and peacefully" (P1955)

"Hold your tongue, woman, this is my affair" (P1955)
\end{abstract}

As to male chauvinist behaviour, it seems worth noting that there are some who criticize the tale King Thrushbeard as portraying dominance of men over women. Yet this particular tale had been incorporated into the East German collection (P1952, K1955, K1956), which might appear contradictory to the socialist belief in equality of men and women. However, the reason underlying the decision to include this tale is rather seen as teaching children the value of honest work.

The lack of parental love is another shortcoming in the aspect of mutual empathy, thus considered untypical of socialist life and, as a result, deleted, as exemplified in the following two tales. The first is taken from Hans the Hedgehog, and it is noteworthy that, this time, Kocialek follows Pollatschek's deletions, signalling that love of parents was non-negotiable in East Germany. Hans the Hedgehog has been living away from his parents in the forest but decides to come home and sends a message to his father.

\footnotetext{
"When his father heard this, he was troubled, because he thought Hans the Hedgehog had died long ago" $(\mathrm{G})$

"But his father had thought Hans the Hedgehog had died long ago" (P1955)
}

However, Hans the Hedgehog does not stay long in the village and announces that he is going away and will never return.

\footnotetext{
"There the father was pleased that Hans (P1955) deleted the Hedgehog did not ever want to return again" (G)
}

The second example (Hansel and Gretel) shows parental cruelty not removed but toned down, by inserting a sentence, telling the children that the mother acted out of desperation and not due to a lack of motherly love for her children. In addition, the East German version omits the concept of stepmother (perhaps owing to its negative connotations) and, also, dissimilar to the original where the stepmother died in the 
end, the mother of the GDR fairy tale stays alive, so as to be overly happy to see her children again, retracting her ill-thinking earlier.

"'I tell you what, husband,' answered the woman, 'early tomorrow morning we will take the children out into the forest to where it is the thickest, ..." (G)
"'I tell you what, husband,' answered the woman, and the misery had hardened her heart, because she did not know what to do any more, 'early tomorrow..." (K1956)

And after the children had returned home:

"The man had not had one happy hour since he had left the children in the forest; the woman, however, was dead" (G)
"The man and the woman had not had one happy hour since they had left the children in the forest" (K1956)

In keeping with the Marxist-Leninist ideology, the concept of work was given high importance. So much so that the phrase "all the bad work" needed to be changed into "all the hard work" (All-kinds-of-Fur; P1953, K1955), since no work was bad but noble and honourable, and that it was felt necessary to re-write the close to the tale The Wishing-table, the Gold-ass and the Cudgel in the Sack.

“... and were all happy and merry. The tailor locked away needle and thread, yard-measure and iron, and lived with his three sons in joy and splendour” (G)
“... and were all happy and merry. Now, you would think that this was going to carry on with eating and drinking and lazing around? Well, there you are mistaken. For a few days, they lived like this. But then the oldest son said, 'I don't like this; that I should not move a finger and should wait for the wishing-table and the gold-ass to serve me.' And the second son said, 'I think, something is missing, if I don't hear the clacking of a mill.' And the third said, 'I have learned my trade diligently and it was an honour to practise it. Should this be the end to it?' So, all the three began to work again, and each made their job better than before and they did not have any more worries.

Only the father locked away needle and thread, yardmeasure and iron, because he was old and had worked enough. But because he also did not want to be lazy, he acquired a new goat which he herded out every day and let her graze..." (P1952)

However, this version of The Wishing-table, the Gold-ass and the Cudgel in the Sack from the year 1952 seemed inadequate three years later; once more Kocialek brought back the original ending in her version (K1955).

Tied in with the theme of work was the notion of initiative and activity. What East German socialists strongly objected to was the belief in God's will and good fortune. In the opinion of the GDR bureaucrats, there was no such thing as God's will but life was what people made of it, and already youngsters were told about the virtue of taking one's life in one's own hands. This attitude was certainly reflected in texts for children; as it was in Grimms' fairy tales. So we read in the following five examples, 


\footnotetext{
"As the new-born boy had a lucky skin on, he was predicted that in his fourteenth year he would have the king's daughter for his wife" (The Devil with the three golden Hairs)

"... and they lived with their father in the greatest happiness as long as it pleased God" (The four skilful Brothers)

"The woman hoped that God was about to grant her desire" (Rapunzel)

"... the parents said that what had befallen her brothers was the will of heaven, and that her birth had only been the innocent cause" (The seven Ravens)
}

"When he was born, he was predicted to have the king's daughter for his wife in his fourteenth year" (P1952)

"... and they lived with their father in the greatest happiness until they died" (P1953, K1955, K1956)

"The woman hoped that her wish would be fulfilled" (P1952)

"... the parents said that it was all such a disaster and that her birth had only been the innocent cause" (P1952)

Such belief accorded fully with the prevailing objective of atheist education. Text comparisons reveal that religion represented an area which produced the greatest proportion of revisions. So, e.g., every single remark of gottlos (ungodly) found in the corpus of fairy tales was adjusted to böse, tückisch, heimtückisch (evil, malicious, spiteful) or was left out altogether. The phrase fromm und gut (pious and good) was another sensitive expression which was, as a rule, changed to lieb und gut (nice and good), freundlich und gut (friendly and good), brav und gut (well-behaved and good) or rein und gut (pure and good). All forms of praying resulted in persistent removal. Also cut without any replacement was the only mention of the Christkind (Christ child; The Bremen Town Musicians) and two mentions of an angel (The Goose Girl at the Well; Snow White and Rose Red). In the case of Snow White and Rose Red this even meant deleting the entire scene in which the girls meet their guardian angel, who had prevented them from falling into a precipice.

In a similar way, baptisms and allusions to them have unacceptable echoes and, to a large degree, were eliminated. In the tale The seven Ravens a girl is born, tiny and sickly and therefore her father wishes to baptise her immediately, so he

“... sent one of the boys in haste to the spring to fetch water for the baptism" (G)
"... sent one of the boys in haste to the spring to fetch water" (P1952)

The six brothers go with the boy; however, the jug falls into the well and the boys do not dare to go home without the water. At home, the father grows impatient, believing that they have forgotten the water for some game. He

\footnotetext{
"became afraid that the girl would have to die without being baptized, and in his anger cried, 'I wish the boys were all turned into ravens."” $(\mathrm{G})$
}

"cried in his anger, 'I wish the boys were all turned into ravens." (P1952)

Yet, by cutting out the reason why the father wanted his son to bring him water, namely to baptise the new-born, the story loses some sense of the connection between the birth of a tiny, sickly child and the father's wish to have water.

In the tale Godfather Death a father rejects God as the godfather to his child because he is of the opinion that God is unfair, as he gives to the rich and leaves the poor to hunger. Of course, from the East German standpoint, there was no objection to this notion; however, the Grimms then continue to explain to the children why the 
man came to think in such a way, i.e., "Thus spoke the man, because he did not know how wisely God apportions riches and poverty," and most certainly this could not be tolerated and had to disappear (P1955, K1955).

An area which did not seem to pose any difficulties were various emotive exclamations, such as "dear God," "oh God," "good Lord" or "God be with you." They were all left in the text untouched. This leads one to believe that, despite mentioning God, they were of minor weight and only depictions of religious significance, e.g., pious practices or holy symbols or images had to go. A similar case in question is the word Jungfrau, which can be translated as maiden but also as virgin and is therefore rich in religious overtones. In the majority of instances, Jungfrau was left in the stories. It is a reasonable guess that the editors thought Jungfrau to be an expression reminiscent of gone-by days and therefore suitable in a text written more than 100 years before and speaking of adventures which took place in a remote past. Nonetheless, the keusche Jungfrau (pure and chaste maiden) in Jorinde und Joringel appears to have been too much and was cut in all three books (P1955, K1955, K1956), the description of 'pure and chaste' is missing.

This leads to the final section, constituting a brief account of stylistic and grammatical modifications employed by the two GDR editors. There is plenty of evidence that they attempted to modernise some of the language, successfully to a significant degree it has to be said. In this endeavour, they also detected two blatant mistakes in the Grimms' stories and put them right. Firstly, in Strong Hans, the Grimms are very clear that Hans is 9 years old when he challenges the robbers' captain for the first time, but fails. After a year he tries again, this time he succeeds; afterwards, he and his mother are able to leave the robbers' cave where they were held prisoners; on coming home, the reader is told that Hans is taller than his father, albeit being only 12 years old. All three East German versions picked up on this error and have the boy's age as 10 (P1955, K1955, K1956). In the second instance (The Raven), the Grimms' original is inconsistent in terms of the colours of the horses with which the king's daughter will come. The princess states that they are white, red and black, yet later she comes with horses of a white, brown and black colour. Again, Pollatschek and Kocialek change the colour to be red (interestingly not brown) to maintain consistency in the narrative (P1955, K1955).

In a similar fashion, they updated some of the language, replacing old German expressions, which were thought incomprehensible for readers, with expressions of their time, e.g.

die Speisen rauchten (the dishes smoked)

(One-eye, Two-eyes and Three-eyes)

mutterseelig allein (all on her own) (Snow White)

es schickt mir selber nicht (it's not enough for me) (The three little Men in the Forest)

aber sie kriegte immer keins (but she never had one) (Little Briar Rose) die Speisen dampften (were steaming with heat) (P1952, K1956)

mutterseelenallein (P1953, K1955)

es genügt mir selber nicht (P1953, K1955, K1956)

aber sie kriegte keins (P1952, K1955)

Nevertheless, both editors let the reader down with some old expressions which they failed to modernise or explain, for instance, Toffeln (Hans the Hedgehog), Lobhucke (The Raven), schnippen (The Devil's sooty Brother). Of course, on the one hand it can 
be argued that this does not really matter; these are minor instances, they can be overlooked easily and do not represent an obstacle to understanding the storyline; on the other hand, in order to present a consistently modernised version of Grimms' fairy tales, research into the meaning of these terms and adjustment or explanations would have been helpful. In The Brave little Tailor, one term however was updated by Pollatschek (P1952) and deserves mention, i.e., Absatz (sales). Although easily understandable by anyone, Absatz has connotations of capitalism associated with it. The use of such words with capitalist stigma attached to them was deemed incompatible with socialist lifestyle and thus frowned upon, in some instances even tabooed. Hence, the woman selling apple sauce and hoping to find good sales, is in Pollatschek's version only allowed to hope to sell a 'fair' amount of her products (The Brave little Tailor). Most strikingly, Kocialek (K1955, K1956) restored the term Absatz, a fact which appears remarkable, considering the rigidity of society and the growing influence of censorship; it can only be explained by the increasing concern about the role and value of original writing and about the ethical hesitancy to be unfaithful to the creator of a piece of art, particularly, as it was also in the beginning of the 1950s that the GDR began to change its legislation in favour of acknowledgement and rights of authorship.

Regarding grammar, on the whole, both editors sought to achieve contemporary grammatical writing; for instance, by updating past participle forms (kriegt -> gekriegt). Inconsistencies emerge with the superlative forms of certain adjectives used as nouns; to exemplify, the oldest, the youngest, the most dangerous. Given that in the German language nouns are written with a capital letter, these noun replacements ought to have been written with capital first letters. However, the East German tales appear somewhat erratic in their choice of capital and small letters. There is lack of consistency within the same volume, sometimes even within the same fairy tale and the reader finds capital and small letters used in a rather unpredictable way.

\section{Conclusion}

Both East German re-issues of Grimms' fairy tales in the first half of the 1950s constituted a distinct domestication of the source texts; Pollatschek's even more so than Kocialek's. Research has shown that a large proportion of the fairy tales was selected because they could be told to a child audience without any modifications. The tales chosen are predominently about human qualities generally applicable to any culture or society (e.g., stories of the character of a fable). Censorship by selection of texts took place in the case of those tales with topics too far from the ideological paradigm. The editors appear to have realized the difficulties such stories would encounter with the censoring authority unless key aspects were removed, which would have resulted in a vast mutilation of the source texts.

Of the 94 tales chosen for the East German market, 52 (i.e., more than 50\%) were changed to greater or lesser degree. The strategies employed were those of modifying references of a general concern for the young audience but also promoting socialist culture by carrying principles and allusions meaningful to the emerging East German society, thereby adapting them to fit into the new environment. Aspects of violence and eroticism are included in the category of general changes. However, the majority of changes performed by the two East German editors revolve around aspects of a socialist lifestyle. From the ideological viewpoint of that time, many alterations seem 
understandable, such as having the royal couple 'live in' their kingdom instead of 'ruling over' it. What, however, is debatable is the extent of some of the changes, by providing, for example, an entirely new ending to a fairy tale, as this alters the story so significantly that its whole impact is changed (one might perhaps say destroyed). Also, whereas fairy tales leave it open to the imagination of the child as to what the fictional characters might do after the ending of the story, these East German re-writes (e.g., The Wishing-table, the Gold-ass and the Cudgel in the Sack) only serve to convey a political point by telling the child exactly how the characters should behave. Modifications and deletions of this kind are nothing new in texts addressed to a child audience. Many opinions have been voiced about such a practice (see e.g., Jones 1992), and it is not the intention here to judge the value of such actions.

Yet, such types of alterations should not come as a surprise. Every community or culture has its own values and conventions suited to its needs in a given time or place. As such, a culture does not represent an inflexible system but a flowing, evolving entity. Within a culture, no agent lives in a vacuum; with respect to children's literature this means that authors, editors, re-writers or translators are in constant interaction with their environment, being influenced but also influencing it. Bearing this in mind, values highly regarded at one particular time, will no longer be so at another; similarly, what is valued may differ from region to region. Hence, the morals and lessons taught to the next generation in every culture are highly likely to vary. What in one society constitutes the true meaning, in another is "often nothing more than an ossified and ossifying bit of wisdom with little relevance to the lives of those who read [the texts]" (Tatar 1992: xvi).

Fairy tales are a kind of literature easily adaptable, as is evidenced by numerous re-writings and adaptations. Certainly, the GDR took advantage of this fact. While ascertaining the importance of the cultural heritage and striving to make accessible works of the German tradition to their readers, East German bureaucracy appears at the same time to have been aware of values portrayed in such writing. Recognizing the outdatedness of some of these values for their own end, they were changed and updated, in order to reflect the needs of the current society. Therefore, despite their respect for the Grimms and their works, East Germany did not accept the concepts and beliefs unthinkingly, but rather these tales were used actively, anchoring them in the socialist reality and shaping them as a useful device of socialisation.

From the mid 1950s fairy tales were increasingly repositioned as products of class-conscious proletarians; they were identified, in fact, as siding with the poor, ascertaining that social conditions were told merely from a proletarian viewpoint; equally, despite their use of magic, they were now increasingly considered truly realistic, as they reflected the predecessors' material conditions and thinking (see e.g., Kahlo 1954; Korn 1952; Meyer 1955). This observation, paired with the gradual opening and liberalisation of literary paradigms in the course of the GDR era would suggest a relaxation in terms of the rendition of the Grimms' tales, particularly when considering the fact that the second (i.e., Kocialek's) edition had already restored much of the original writing. How this trend developed in the years following is the task of future research and may provide material for another story... 


\section{REFERENCES}

\section{Primary sources}

Kinder- und Hausmärchen, gesammelt durch die Brüder Grimm. Vollständige Ausgabe mit einer Einleitung von Herman Grimm und einer Vorrede der Brüder Grimm zur ersten Gesamtausgabe von 1819 (1978), licensed edition by Deutscher Bücherbund Stuttgart.

Kocialek, A. (1955ed): Die Kinder- und Hausmärchen der Brüder Grimm I, Berlin, Kinderbuchverlag.

Kocialek, A. (1956ed): Die Kinder- und Hausmärchen der Brüder Grimm II, Berlin, Kinderbuchverlag.

Pollatschek, W. (1952ed): Die Kinder- und Hausmärchen der Brüder Grimm I, Berlin, Kinderbuchverlag.

Pollatscheк, W. (1953ed): Die Kinder- und Hausmärchen der Brüder Grimm II, Berlin, Kinderbuchverlag.

Pollatscheк, W. (1955ed): Die Kinder- und Hausmärchen der Brüder Grimm III, Berlin, Kinderbuchverlag.

Tales collected by the Brothers Grimm <http: //www.ucs.mun.ca/ wbarker/fairies/grimm/> (accessed 14 March 2005).

\section{Secondary sources}

BäHring, H. (1962): Die Absatzabteilung im sozialistischen Verlag, Reihe Verlagsökonomik, Lehrbriefe für das Fachschulfernstudium Leipzig, Fachschule für Buchhändler.

Brandt, S. (1951): 'Wie stehen wir heute zum Märchen? Eine wichtige pädagogische Betrachtung,' Bösenblatt für den Deutschen Buchhandel 26, pp. 321-322.

Der Kinderbuchverlag (1963): 'Verlagsthemenplanung 1963', DR1/1239 SAPMO-Bundesarchiv Berlin (no pages).

Emmrich, C. (1987): Literatur und Medienkünste für junge Leute, Berlin, Kinderbuchverlag.

Göritz, S. (1986): 'Katschelap alias Rumpelstilzchen oder die Verwandlungen eines Märchens', in Schauplatz. Aufsätze zur Kinder- und Jugendliteratur und anderen Medienkünsten, Berlin, Kinderbuchverlag.

Holland, B. (2000): Private Kinder- und Jugendbuchverlage in der DDR. Dargestellt am Beispiel der Verlag 'Altberliner Verlag Lucie Groszer' und 'Alfred Holz Verlag,' unpublished M.A. dissertation, University of Leipzig.

Honecker, M. (1971): 'Zum Erbe und zur Gegenwartsliteratur', Beiträge zur Kinder- und Jugendliteratur 21 , pp. $70-74$.

Jones, G. (1992): “HC and PC," Professional Translator and Interpreter 3, pp. 18-20.

Kahlo, G. (1954): Die Wahrheit des Märchens, Halle/S, VEB Max Niemeyer.

Kamenetsky, C. (1992): The Brothers Grimm and their Critics. Folktales and the Quest for Meaning, Ohio, Ohio University Press.

Korn, I. (1952): 'Zum deutschen Volksmärchen. Eine Anregung zur Diskussion,' Der Bibliothekar $7 / 8$, pp. 437-451.

Meyer, H. (1955): 'Neue Märchenbücher', Die Buchbesprechung 12, pp. 753-754.

Rumland, M.-K. (1993): Veränderungen in Verlagswesen und Buchhandel der ehemaligen DDR 1989-1991, Wiesbaden, Harrassowitz.

Streul, I. C. (1988): Westdeutsche Literatur in der DDR. Böll, Grass, Walser und andere in der offiziellen Rezeption 1949-1985 Stuttgart: Metzler.

Tatar, M. (1992): Off with their heads. Fairy tales and the culture of childhood, Princeton, New Jersey, Princeton University Press.

Wardetzky, K. (1991): Märchen-Lesarten von Kindern. Eine empirische Studie zum Verhältnis 6 bis 10 Jähriger zum Märchen, Ph.D. thesis, Berlin, Humboldt Universität.

Wiesner, H. (1991): Zensiert-Gefördert-Verhindert. Ausstellung 'Zensur in der Deutschen Demokratischen Republik,' Berlin, Literaturhaus Berlin. 
Wille Hermann, H. (1951): 'Unsere Kinder brauchen gute Bücher', Börsenblatt für den Deutschen Buchhandel 26, pp. 318-320.

Zweig, A. (1948): 'Der Jude im Dorn,' Ost und West 11, pp. 58-65.

\section{APPENDIX}

List of all tales included in one or more East German volumes (in alphabetical order):

P1952 = Pollatschek's version from the year 1952

P1953 = Pollatschek's version from the year 1953

P1955 = Pollatschek's version from the year 1955

K1955 = Kocialek's version from the year 1955

K1956 = Kocialek's version from the year 1956

$\mathrm{M}=$ rendered with modifications in the East German versions

$\mathrm{U}=$ rendered unchanged in the East German versions

\begin{tabular}{|c|c|c|c|c|c|c|c|}
\hline English & German & P1952 & P1953 & P1955 & K1955 & K1956 & Ed \\
\hline All-kinds-of-Fur & Allerleirauh & & $\checkmark$ & & $\checkmark$ & & $\mathrm{M}$ \\
\hline $\begin{array}{l}\text { Cat and Mouse in } \\
\text { Partnership }\end{array}$ & $\begin{array}{l}\text { Katze und Maus in } \\
\text { Gesellschaft }\end{array}$ & $\checkmark$ & & & & & $\mathrm{M}$ \\
\hline Cinderella & Aschenputtel & & $\checkmark$ & & $\checkmark$ & & $\mathrm{M}$ \\
\hline Clever Grethel & Die kluge Gretel & & & & $\checkmark$ & & $\mathrm{U}$ \\
\hline Dr Know-all & Doktor Allwissend & & $\checkmark$ & & & & $\mathrm{U}$ \\
\hline Faithful John & Der treue Johannes & & & $\checkmark$ & $\checkmark$ & & $\mathrm{U}$ \\
\hline $\begin{array}{l}\text { Frau Holle (Mother } \\
\text { Holle) }\end{array}$ & Frau Holle & $\checkmark$ & & & $\checkmark$ & & $\mathrm{M}$ \\
\hline $\begin{array}{l}\text { Frederick and } \\
\text { Catherine }\end{array}$ & $\begin{array}{l}\text { Der Frieder und das } \\
\text { Katerlieschen }\end{array}$ & & & & $\checkmark$ & $\checkmark$ & $\mathrm{U}$ \\
\hline Godfather Death & Der Gevatter Tod & & & $\checkmark$ & $\checkmark$ & & $\mathrm{M}$ \\
\hline Hans in Luck & Hans im Glück & & & & $\checkmark$ & & $\mathrm{M}$ \\
\hline Hans the Hedgehog & Hans mein Igel & & & $\checkmark$ & $\checkmark$ & & $\mathrm{M}$ \\
\hline Hansel and Gretel & Hänsel und Gretel & & & & & $\checkmark$ & $\mathrm{M}$ \\
\hline $\begin{array}{l}\text { How six Men got on in } \\
\text { the World }\end{array}$ & $\begin{array}{l}\text { Sechse kommen durch } \\
\text { die ganze Welt }\end{array}$ & $\checkmark$ & & & & & $\mathrm{M}$ \\
\hline Iron John & Der Eisenhans & & $\checkmark$ & & $\checkmark$ & & $\mathrm{M}$ \\
\hline Jorinde and Joringel & Jorinde und Joringel & & & $\checkmark$ & $\checkmark$ & $\checkmark$ & $\mathrm{M}$ \\
\hline King Thrushbeard & König Drosselbart & $\checkmark$ & & & $\checkmark$ & $\checkmark$ & $\mathrm{M}$ \\
\hline Lazy Harry & Der faule Heinz & & & $\checkmark$ & $\checkmark$ & & $\mathrm{U}$ \\
\hline Little Briar Rose & Dornröschen & $\checkmark$ & & & $\checkmark$ & & $\mathrm{U}$ \\
\hline $\begin{array}{l}\text { Little Brother and little } \\
\text { Sister }\end{array}$ & $\begin{array}{l}\text { Brüderchen und } \\
\text { Schwesterchen }\end{array}$ & & $\checkmark$ & & $\checkmark$ & & $\mathrm{M}$ \\
\hline $\begin{array}{l}\text { Little Louse and little } \\
\text { Flea }\end{array}$ & $\begin{array}{l}\text { Läuschen und } \\
\text { Flöhchen }\end{array}$ & & & & & $\checkmark$ & $\mathrm{U}$ \\
\hline $\begin{array}{l}\text { Little Red-Cap (Little } \\
\text { Red Riding-Hood) }\end{array}$ & Rotkäppchen & $\checkmark$ & & & $\checkmark$ & & $\mathrm{M}$ \\
\hline Little Snow White & Schneewittchen & & $\checkmark$ & & $\checkmark$ & & $\mathrm{M}$ \\
\hline Old Sultan & Der alte Sultan & & $\checkmark$ & & & & $\mathrm{U}$ \\
\hline $\begin{array}{l}\text { One-eye, Two-eyes and } \\
\text { Three-eyes }\end{array}$ & $\begin{array}{l}\text { Einäuglein, } \\
\text { Zweiäuglein und } \\
\text { Dreiäuglein }\end{array}$ & $\checkmark$ & & & & $\checkmark$ & $\mathrm{M}$ \\
\hline Rapunzel & Rapunzel & $\checkmark$ & & & & & $\mathrm{M}$ \\
\hline Rumpelstiltskin & Rumpelstilzchen & & $\checkmark$ & & $\checkmark$ & & $\mathrm{M}$ \\
\hline
\end{tabular}




\begin{tabular}{|c|c|c|c|c|c|c|c|}
\hline $\begin{array}{l}\text { Sharing Joy and } \\
\text { Sorrow }\end{array}$ & Lieb und Leid teilen & & & & & $\checkmark$ & $\mathrm{U}$ \\
\hline Simeli Mountain & Simeliberg & & & $\checkmark$ & & & $\mathrm{U}$ \\
\hline $\begin{array}{l}\text { Snow White and Rose } \\
\text { Red }\end{array}$ & $\begin{array}{l}\text { Schneeweißchen und } \\
\text { Rosenrot }\end{array}$ & & & $\checkmark$ & $\checkmark$ & & M \\
\hline Straw, Coal and Bean & $\begin{array}{l}\text { Strohhalm, Kohle und } \\
\text { Bohne }\end{array}$ & $\checkmark$ & & & & $\checkmark$ & $\mathrm{U}$ \\
\hline Strong Hans & Der starke Hans & & & $\checkmark$ & $\checkmark$ & $\checkmark$ & $\mathrm{M}$ \\
\hline Sweet Porridge & Der süße Brei & $\checkmark$ & & & & & $\mathrm{U}$ \\
\hline $\begin{array}{l}\text { The Bevil's sooty } \\
\text { Brother }\end{array}$ & $\begin{array}{l}\text { Des Teufels rußiger } \\
\text { Bruder }\end{array}$ & & $\checkmark$ & & & & $\mathrm{U}$ \\
\hline The blue Light & Das blaue Licht & & $\checkmark$ & & & $\checkmark$ & $\mathrm{M}$ \\
\hline The brave little Tailor & $\begin{array}{l}\text { Das tapfere } \\
\text { Schneiderlein }\end{array}$ & $\checkmark$ & & & $\checkmark$ & $\checkmark$ & $\mathrm{M}$ \\
\hline $\begin{array}{l}\text { The Bremen Town } \\
\text { Musicians }\end{array}$ & $\begin{array}{l}\text { Die Bremer } \\
\text { Stadtmusikanten }\end{array}$ & $\checkmark$ & & & $\checkmark$ & & $\mathrm{M}$ \\
\hline The crystal Ball & Die Kristallkugel & & & & & $\checkmark$ & $\mathrm{U}$ \\
\hline $\begin{array}{l}\text { The cunning little } \\
\text { Tailor }\end{array}$ & $\begin{array}{l}\text { Vom klugen } \\
\text { Schneiderlein }\end{array}$ & & $\checkmark$ & & & & $\mathrm{U}$ \\
\hline $\begin{array}{l}\text { The Devil and his } \\
\text { Grandmother }\end{array}$ & $\begin{array}{l}\text { Der Teufel und seine } \\
\text { Großmutter }\end{array}$ & & & & & $\checkmark$ & $\mathrm{U}$ \\
\hline $\begin{array}{l}\text { The Devil with the } \\
\text { three golden Hairs }\end{array}$ & $\begin{array}{l}\text { Der Teufel mit den drei } \\
\text { goldenen Haaren }\end{array}$ & $\checkmark$ & & & & & M \\
\hline $\begin{array}{l}\text { The Ditmarsh Tale of } \\
\text { Wonders }\end{array}$ & $\begin{array}{l}\text { Das Dietmarsische } \\
\text { Lügenmärchen }\end{array}$ & & $\checkmark$ & & & & $\bar{U}$ \\
\hline The Elves & Die Wichtelmänner & & $\checkmark$ & & $\checkmark$ & & $\mathrm{M}$ \\
\hline $\begin{array}{l}\text { The Fisherman and his } \\
\text { Wife }\end{array}$ & $\begin{array}{l}\text { Von dem Fischer und } \\
\text { syner Frau }\end{array}$ & & & $\checkmark$ & $\checkmark$ & & $\mathrm{U}$ \\
\hline $\begin{array}{l}\text { The four skilful } \\
\text { Brothers }\end{array}$ & $\begin{array}{l}\text { Die vier kunstreichen } \\
\text { Brüder }\end{array}$ & & $\checkmark$ & & $\checkmark$ & $\checkmark$ & $\mathrm{M}$ \\
\hline The Fox and the Cat & $\begin{array}{l}\text { Der Fuchs und die } \\
\text { Katze }\end{array}$ & & & $\checkmark$ & $\checkmark$ & & $\mathrm{U}$ \\
\hline The Fox and the Geese & $\begin{array}{l}\text { Der Fuchs und die } \\
\text { Gänse }\end{array}$ & & $\checkmark$ & & $\checkmark$ & & $\mathrm{U}$ \\
\hline The Fox and the Horse & $\begin{array}{l}\text { Der Fuchs und das } \\
\text { Pferd }\end{array}$ & & & & & $\checkmark$ & $\mathrm{U}$ \\
\hline $\begin{array}{l}\text { The Frog King or Iron } \\
\text { Henry }\end{array}$ & $\begin{array}{l}\text { Der Froschkönig oder } \\
\text { der eiserne Heinrich }\end{array}$ & & $\checkmark$ & & $\checkmark$ & $\checkmark$ & $\mathrm{U}$ \\
\hline The Gnome & Dat Erdmänneken & & & $\checkmark$ & & & $\mathrm{M}$ \\
\hline The Gold-children & Die Goldkinder & & & $\checkmark$ & $\checkmark$ & & $\mathrm{U}$ \\
\hline The golden Bird & Der goldene Vogel & & $\checkmark$ & & $\checkmark$ & & $\mathrm{M}$ \\
\hline The golden Goose & Die goldene Gans & $\checkmark$ & & & & $\checkmark$ & $\mathrm{M}$ \\
\hline The golden Key & Der goldene Schlüssel & & & $\checkmark$ & & & $\mathrm{U}$ \\
\hline The Goose Girl & Die Gänsemagd & & & $\checkmark$ & $\checkmark$ & & $\mathrm{M}$ \\
\hline $\begin{array}{l}\text { The Goose Girl at the } \\
\text { Well }\end{array}$ & $\begin{array}{l}\text { Die Gänsehirtin am } \\
\text { Brunnen }\end{array}$ & & & $\checkmark$ & $\checkmark$ & $\checkmark$ & M \\
\hline The Griffin & Der Vogel Greif & & & $\checkmark$ & & & $\mathrm{M}$ \\
\hline $\begin{array}{l}\text { The Hare and the } \\
\text { Hedgehog }\end{array}$ & Der Hase und der Igel & & & $\checkmark$ & $\checkmark$ & & $\mathrm{M}$ \\
\hline The Hut in the Forest & Das Waldhaus & $\checkmark$ & & & & & $\mathrm{M}$ \\
\hline The Master Thief & Der Meisterdieb & & & $\checkmark$ & $\checkmark$ & $\checkmark$ & $\mathrm{M}$ \\
\hline
\end{tabular}




\begin{tabular}{|c|c|c|c|c|c|c|c|}
\hline The nail & Der Nagel & & & & & $\checkmark$ & $\mathrm{U}$ \\
\hline $\begin{array}{l}\text { The Nixie of the Mill- } \\
\text { pond }\end{array}$ & Die Nixe im Teich & & & $\checkmark$ & $\checkmark$ & & $\mathrm{U}$ \\
\hline $\begin{array}{l}\text { The old Man and his } \\
\text { Grandson }\end{array}$ & $\begin{array}{l}\text { Der alte Großvater und } \\
\text { der Enkel }\end{array}$ & $\checkmark$ & & & & $\checkmark$ & $\mathrm{U}$ \\
\hline $\begin{array}{l}\text { The Pack of } \\
\text { Ragamuffins }\end{array}$ & Das Lumpengesindel & & $\checkmark$ & & & & $\mathrm{U}$ \\
\hline $\begin{array}{l}\text { The Peasant and the } \\
\text { Devil }\end{array}$ & $\begin{array}{l}\text { Der Bauer und der } \\
\text { Teufel }\end{array}$ & & & $\checkmark$ & $\checkmark$ & & $\mathrm{U}$ \\
\hline The Peasant in Heaven & Das Bürle im Himmel & & & & & $\checkmark$ & $\mathrm{U}$ \\
\hline $\begin{array}{l}\text { The Peasant's clever } \\
\text { Daughter }\end{array}$ & $\begin{array}{l}\text { Die kluge } \\
\text { Bauerntochter }\end{array}$ & & & $\checkmark$ & $\checkmark$ & $\checkmark$ & M \\
\hline $\begin{array}{l}\text { The poor Miller's Boy } \\
\text { and the Cat }\end{array}$ & \begin{tabular}{|l|} 
Der arme \\
Müllerbursch und das \\
Kätzchen
\end{tabular} & & $\checkmark$ & & $\checkmark$ & & $\mathrm{U}$ \\
\hline The Queen Bee & Die Bienenkönigin & $\checkmark$ & & & & & $\mathrm{U}$ \\
\hline The Raven & Die Rabe & & & $\checkmark$ & $\checkmark$ & & $\mathrm{M}$ \\
\hline The Sea-hare & Das Meerhäschen & & & $\checkmark$ & $\checkmark$ & & $\mathrm{U}$ \\
\hline The seven Ravens & Die sieben Raben & $\checkmark$ & & & & & $\mathrm{M}$ \\
\hline The seven Swabians & Die sieben Schwaben & & & $\checkmark$ & & & $\mathrm{M}$ \\
\hline The Shepherd Boy & Das Hirtenbüblein & & & $\checkmark$ & & & $\mathrm{U}$ \\
\hline $\begin{array}{l}\text { The Shoes that were } \\
\text { danced to Pieces }\end{array}$ & Die zertanzten Schuhe & & & $\checkmark$ & & & M \\
\hline $\begin{array}{l}\text { The singing, springing } \\
\text { Lark }\end{array}$ & \begin{tabular}{|l|} 
Das singende, \\
springende \\
Löweneckerchen \\
\end{tabular} & & $\checkmark$ & & $\checkmark$ & & $\mathrm{M}$ \\
\hline The six Swans & Die sechs Schwäne & & & & & $\checkmark$ & $\mathrm{M}$ \\
\hline The Spirit in the Bottle & Der Geist im Glas & & $\checkmark$ & & & & $\mathrm{M}$ \\
\hline $\begin{array}{l}\text { The Story of the Youth } \\
\text { who went forth to } \\
\text { learn what Fear was }\end{array}$ & $\begin{array}{l}\text { Märchen von einem, } \\
\text { der auszog, das } \\
\text { Fürchten zu lernen } \\
\end{array}$ & & $\checkmark$ & & & $\checkmark$ & $\mathrm{M}$ \\
\hline $\begin{array}{l}\text { The three Children of } \\
\text { Fortune }\end{array}$ & Die drei Glückskinder & & & & & $\checkmark$ & $\mathrm{U}$ \\
\hline The three Feathers & Die drei Federn & & $\checkmark$ & & & & $\mathrm{M}$ \\
\hline The three little Birds & De drei Vügelkens & & & & & $\checkmark$ & $\mathrm{M}$ \\
\hline $\begin{array}{l}\text { The three little Men in } \\
\text { the Forest }\end{array}$ & $\begin{array}{l}\text { Die drei Männlein im } \\
\text { Walde }\end{array}$ & & $\checkmark$ & & $\checkmark$ & $\checkmark$ & $\mathrm{M}$ \\
\hline The three Sluggards & Die drei Faulen & & & & & $\checkmark$ & $\mathrm{U}$ \\
\hline The twelve Huntsmen & Die zwölf Jäger & & $\checkmark$ & & $\checkmark$ & $\checkmark$ & $\mathrm{U}$ \\
\hline The two Brothers & Die zwei Brüder & & $\checkmark$ & & $\checkmark$ & & $\mathrm{M}$ \\
\hline The Water of Life & Das Wasser des Lebens & $\checkmark$ & & & & & $\mathrm{U}$ \\
\hline The whilte Snake & Die weiße Schlange & & $\checkmark$ & & & & $\mathrm{M}$ \\
\hline $\begin{array}{l}\text { The Willow-wren and } \\
\text { the Bear }\end{array}$ & $\begin{array}{l}\text { Der Zaunkönig und } \\
\text { der Bär } \\
\end{array}$ & & & $\checkmark$ & & $\checkmark$ & $\mathrm{U}$ \\
\hline $\begin{array}{l}\text { The Wishing-table, the } \\
\text { Gold-ass and the } \\
\text { Cudgel in the Sack }\end{array}$ & $\begin{array}{l}\text { Tischchen deck dich, } \\
\text { Goldesel und Knüppel } \\
\text { aus dem Sack }\end{array}$ & $\checkmark$ & & & $\checkmark$ & & $\mathrm{M}$ \\
\hline The Wolf and the Fox & $\begin{array}{l}\text { Der Wolf und der } \\
\text { Fuchs }\end{array}$ & & 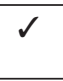 & & & & $\mathrm{U}$ \\
\hline The Wolf and the Man & $\begin{array}{l}\text { Der Wolf und der } \\
\text { Mensch }\end{array}$ & & & $\checkmark$ & $\checkmark$ & $\checkmark$ & $\mathrm{U}$ \\
\hline
\end{tabular}




\begin{tabular}{|l|l|c|c|c|c|c|c|}
\hline $\begin{array}{l}\text { The Wolf and the } \\
\text { seven young Kids }\end{array}$ & $\begin{array}{l}\text { Der Wolf und die } \\
\text { sieben jungen Geißlein }\end{array}$ & $\checkmark$ & & & $\checkmark$ & & M \\
\hline The young Giant & Der junge Riese & & & $\checkmark$ & $\checkmark$ & & M \\
\hline Thumbling & Daumesdick & & $\checkmark$ & & $\checkmark$ & & U \\
\hline
\end{tabular}

